\title{
Lipid and lipopolysaccharide constituents of cyanobacterium Spirulina platensis (Cyanophyceae, Nostocales)
}

\author{
T. G. Tornabene, T. F. Bourne, S. Raziuddin \& A. Ben-Amotz* \\ School of Applied Biology, Georgia Institute of Technology, Atlanta, Georgia 30332, USA
}

\begin{abstract}
Nature and quantity of lipids and lipopolysaccharides of Spirulina platensis were examined. Organic cell weight consisted of $50 \%$ protein, $8.8 \%$ carbohydrate and $16.6 \%$ lipids. Carotenoid-to-chlorophyll ratio was 0.3. Lipids consisted of a diverse assortment of pigments, hydrocarbons, glycolipids, and phosphatidyl glycerol. Fatty acid contents were predominantly even-numbered chains with a relatively high proportion of polyunsaturated fatty acids. Lipopolysaccharide consisted of unsaturated fatty acids, 3-hydroxy myristate and the.carbohydrates, hexoses, heptose, octulosonic acid and glucosamine. Assays of the lipopolysaccharide preparation by the Limulus amoebocyte lysate test and by the lethal toxicity test in mice demonstrated that the lipopolysaccharide of $S$. platensis is toxic but its toxicity is in the order of $10 \%$ of the lipopolysaccharide fraction of Salmonella abortus.
\end{abstract}

\section{INTRODUCTION}

Spirulina platensis is a filamentous cyanobacterium that grows in salty and fresh water lakes and ponds. It contains more than $50 \%$ protein and is commercially accepted as a dietary protein source and as health food (Richmond et al. 1982, Vonshak et al. 1982, Yanagimoto \& Saitoh 1982, Vonshak et al. 1983). Biologically, Cyanophytes are curious organisms since they are photosynthetic prokaryotes that contain the basic structure and chemical composition of the cell wall of Gram-negative bacteria while possessing a photosynthesis apparatus like that found in eukaryotes. They contain lipopolysaccharides (LPS) (Weise et al. 1970, Weckesser et al. 1974, Stanier \& Cohen-Bazire 1977, Weckesser et al. 1979, Keleti et al. 1981) that are characteristic of most Gram-negative bacteria and well recognized as an endotoxic and antigenic component of the cell wall. The lipid composition is relatively simple, containing principally mono- and di-galactosyl diacylglycerides, phosphatidyl diacylglycerol and sulfoquinovosyl diacylglycerol (Appleby et al. 1971, Sato et al. 1979, Sato \& Murata 1982). Only a few of the Cyanophytes are recognized as producers of toxins

\footnotetext{
- Present address and address for correspondence: Israel Oceanographic \& Limnological Research Ltd., P. O. Box 8030 , Haifa, Israel 31080
}

(Gentile 1971, Carmichael \& Gorham 1980) that cause animal poisonings.

The present report describes the lipid and LPS properties of Spirulina platensis.

\section{MATERIALS AND METHODS}

Spirulina platensis Lb 1475/4a was cultivated as previously described (Vonshak et al. 1982), harvested by filtration and spray-dried. Cell suspensions were extracted for lipids by the modified method of Bligh and Dyer (1959) (Kates et al. 1964). Nonpolar and polar lipids were separated by silicic acid columnchromatography (Tornabene et al. 1969) with hexane, benzene, chloroform, acetone and methanol. LPS was extracted from dried cells by the phenol-water method (Westphal et al. 1952). LPS was isolated by isopycnic density gradient ultracentrifugation. Lipid components were deacylated by mild alkaline methanolysis (Tornabene \& Ogg 1971). Sample was hydrolyzed with $2 \mathrm{~N} \mathrm{HCl}$ at $100^{\circ} \mathrm{C}$ for $2 \mathrm{~h}$ for neutral sugars; $4 \mathrm{~N} \mathrm{HCl}$ for $6 \mathrm{~h}$ at $100^{\circ} \mathrm{C}$ for amino sugars; and $0.025 \mathrm{~N}$ sulfuric acid for $1 \mathrm{~h}$ at $100^{\circ} \mathrm{C}$ for ketodeoxyoctulosonic acid (KDO). Lipids were analysed by thin-layer chromatography in diethyl ether-benzene-ethanol-acetic acid (45:50:2:0.2) as first solvent and hexane-diethyl ether (96:4) as second solvent or chloroform-acetone-me- 
thanol-acetic acid-water $(50: 20: 10: 10: 5)$. Lipids were detected by exposure to $I_{2}$ vapor, acid charring, phosphate spray (Vaskovsky \& Svetashev 1972), ninhydrin, $\alpha$-napthol for glycolipids (Kates 1971), Dragendorff stain for quartenary amines (Kates 1971), or $\mathrm{H}_{2} \mathrm{SO}_{4}$ acetic acid (1:1) for sterols (Kates 1971). The deacylated water-soluble products were separated on cellulose-TLC plates (Short et al. 1969). Samples were made visible by the o-tolidine staining method overstained with an acidic ammonium molybdate solution (Kates 1971), or by ninhydrin. Total carbohydrates were determined by the phenol-sulfuric acid method (Kochert 1973b). Nucleic acids were estimated spectrophotometrically after hydrolysis with $0.1 \mathrm{~N} \mathrm{NaOH}$. Total protein was determined after hydrolysis in $\mathrm{NaOH}$ at $100^{\circ} \mathrm{C}$ at $1 \mathrm{~h}$ (Kochert 1973a). Samples were assayed for 3-deoxy sugars (Cynkin \& Ashwell 1960), KDO (Warren 1959), glucosamine (Boas 1953), heptose (Wright \& Rebers 1972), and phosphorus (Bartlett 1959). Total fatty acid of LPS were determined gravimetrically (Raziuddin 1976). Chlorophyll and carotenoids were assayed as described by Jensen (1973). Fatty acids were converted to the methyl ester form in $2.5 \%$ anhydrous methanolic-HCl (Kates 1971). Aliquots of fatty acids were hydrogenated with $\mathrm{H}_{2}$ and $10 \% \mathrm{Pd}$ on activated charcoal. Free sugars were converted to alditol acetates (Albersheim et al. 1967). Derivatized components were analysed on a Varian 3700 gas-liquid chromatograph (GLC) equipped with dual flame ionization detectors and a Varian Vista 401 data systems. The following columns were used: $30 \times 0.252 \mathrm{~mm}$ fused quartz capillary column, with $0.25 \mu \mathrm{M}$ of OV 351 or $0.25 \mu \mathrm{M}$ of DB-5 at 8 psi of $\mathrm{He}$ and $4{ }^{\circ} \mathrm{C} \mathrm{min}^{-1}$ from 125 to $220^{\circ} \mathrm{C}$ and held isothermally; $2 \mathrm{~m} \times 0.31 \mathrm{~cm}$ glass column packed with $10 \%$ SP2330 on 100/120 Gas Chrom W AW at 27 psi of He and $4{ }^{\circ} \mathrm{C} \mathrm{min}$ m $^{-1}$ from 100 to $250^{\circ} \mathrm{C}$ and held isothermally.

The Limulus amoebocyte lysate test was performed by mixing $0.1 \mathrm{ml}$ of the lysate and $0.1 \mathrm{ml}$ of sample and incubating at $37^{\circ} \mathrm{C}$. The mixtures were examined after $1 \mathrm{~h}$ and $24 \mathrm{~h}$ of incubation. A negative control of pyrogen-free saline and positive control of Spirulina abortus equi LPS were used. Mouse lethality tests of LPS were conducted using C57BL/6 male mice, 6 to $7 \mathrm{wk}$ of age. Mice were injected intraperitoneally, and 6 mice were used for each concentration; deaths were recorded after $48 \mathrm{~h}$.

\section{RESULTS}

Spray-dried Spirulina platensis contained $16.6 \%$ lipid, $8.8 \%$ carbohydrate and $50 \%$ protein. In agreement with previous observations (Yanagimoto \& Saitoh
1982), the carotenoid-to-chlorophyll ratio was about 0.3 .

Most of the total lipids fractionated on a silicic acid column eluted with acetone and methanol. Combined hexane, benzene and chloroform eluates comprised only $5 \%$ of the total lipids. The hexane fraction comprised only $0.2 \%$ of the total lipids. Three components were identified in the hexane fraction by GLC; they were pentadecane $(5.5 \%)$, hexadecane $(4.3 \%)$, and heptadecane $(90 \%)$ as previously reported (Tornabene 1980). No unsaturated and branched hydrocarbons were detected. The benzene eluate representing $3.4 \%$ of total lipids consisted of 5 components when analysed by TLC. Four of the components were yellowcolored pigments; the fourth component cochromatographed with a sterol ester standard. The component stained red with $\mathrm{H}_{2} \mathrm{SO}_{4}$ and acetic acid indicating a sterol component; however, no sterol was recovered after methanolic- $\mathrm{HCl}$ hydrolysis and analysis by the chromatographic procedures. The components were not identified. The chloroform eluate comprised only $1.4 \%$ of the total lipids and appeared to consist of 4 components, 2 of which are yellow pigmented. Components in relatively low concentrations cochromatographed with a triglyceride, a free fatty acid, and a hydrocarbon standard.

The acetone and methanol eluates contained all of the polar lipids which represented $95 \%$ of total lipids. In addition to the assortment of green, yellow, orange, and rose colored pigments fractionated by TLC, several components cochromatographed with authentic standards. On the basis of the $R_{f}$ values, and staining behavior, they were tentatively identified as monogalactosyl diacylglyceride, phosphatidyl diacylglyceride, digalactosyl diacylglyceride and sulfoquinovosyl diacylglyceride. A major phosphate containing component and a glycolipid were also detected by differential staining procedures on TLC. The components were identified as phosphatidyl monoacylglycerol and digalactosyl monoacylglycerol after mild alkaline hydrolysis, cellulose-TLC and GLC.

The fatty acid composition is summarized in Table 1. Fatty acids are principally even-numbered carbon chains with a relatively large proportion of them being unsaturated. The existence of the polyunsaturated chains (Table 1) was substantiated by GLC of the hydrogenated components.

The LPS of Spirulina platensis comprised $1.6 \%$ of the cellular dry weight. The LPS fraction was soluble in water and $1 \%$ Triton X-100 but not in acetone, ethanol or pyridine. The chemical composition of the LPS is given in Table 2. It was free of nucleic acids but contained traces of proteins $(0.6 \%)$. The total carbohydrate $(31.6 \%)$ and fatty acids $(14.3 \%)$ represented $46 \%$ of the LPS composition. Sugar analysis revealed 
Table 1. Spirulina platensis. Relative retention and percentage composition data of fatty acids

\begin{tabular}{|c|c|c|c|c|c|}
\hline \multirow[b]{3}{*}{$\begin{array}{l}\text { Fatty } \\
\text { acid }\end{array}$} & \multirow[b]{3}{*}{$\begin{array}{l}\text { Ret. time } \\
\text { (min) }\end{array}$} & \multicolumn{4}{|c|}{ Relative percent } \\
\hline & & \multicolumn{2}{|c|}{ Total lipids } & \multicolumn{2}{|c|}{ LPS } \\
\hline & & $\begin{array}{l}\text { unhydro- } \\
\text { genated }\end{array}$ & $\begin{array}{l}\text { hydro- } \\
\text { genated }\end{array}$ & $\begin{array}{l}\text { unhydro- } \\
\text { genated }\end{array}$ & $\begin{array}{l}\text { hydro- } \\
\text { genated }\end{array}$ \\
\hline $14: 0$ & 19.0 & 0.8 & 1.6 & - & - \\
\hline $14: 1$ & 19.6 & 0.6 & - & - & - \\
\hline $16: 0$ & 24.1 & 26.4 & 38.9 & 9.5 & 19.8 \\
\hline $16: 1$ & 24.8 & 4.6 & - & 10.4 & - \\
\hline $16: 2$ & 26.5 & 1.0 & - & - & - \\
\hline $16: 3$ & 29.2 & 2.1 & - & - & - \\
\hline $17: 0$ & 26.9 & 0.7 & 0.7 & 3.1 & 3.0 \\
\hline $18: 0$ & 30.0 & 0.4 & 55.5 & 1.5 & 64.1 \\
\hline $18: 1$ & 30.9 & 22.8 & - & 1.7 & - \\
\hline $18: 2$ & 32.6 & 9.8 & - & 5.0 & - \\
\hline $3-\mathrm{OH}-14: 0$ & 33.1 & - & - & 9.6 & 9.4 \\
\hline $18: 3$ & 35.3 & 21.1 & - & 55.3 & - \\
\hline $19: 0$ & 34.0 & 3.5 & 0.7 & - & - \\
\hline $3-\mathrm{OH}-16: 0$ & 45.3 & - & - & 2.1 & 2.0 \\
\hline Unidentified & $(16-46)$ & 6.2 & - & 1.8 & - \\
\hline
\end{tabular}

Table 2. Spirulina platensis. Chemical composition of lipopolysaccharides

\begin{tabular}{|c|c|}
\hline Components & $\begin{array}{c}\text { Lipopolysaccharides } \\
\% \text { of the total }\end{array}$ \\
\hline Glycerola $^{a}$ & 7.4 \\
\hline Glucose $e^{a}$ & 7.5 \\
\hline Rhamnose $^{a}$ & 17.1 \\
\hline Fucose $\mathrm{e}^{\mathrm{a}}$ & 3.3 \\
\hline Ribose $^{\mathrm{a}}$ & 8.1 \\
\hline Xylose $\mathrm{e}^{\mathrm{a}}$ & 4.5 \\
\hline 3- or 4-0-Methyl hexose ${ }^{a}$ & 8.1 \\
\hline Mannose & 1.9 \\
\hline Galactose $^{a}$ & 8.2 \\
\hline Inositolà & 6.0 \\
\hline D-Glycero-D-mannoheptose ${ }^{a}$ & 1.6 \\
\hline D-Glycero-L-mannoheptose ${ }^{a}$ & 3.7 \\
\hline Unidentifieda & 22.6 \\
\hline Heptose $e^{b}$ & 1.4 \\
\hline 3-Deoxy-D-manno-octulosonic acid & 1.2 \\
\hline D-Glucosamine & 2.1 \\
\hline Total carbohydrates ${ }^{b}$ & 31.6 \\
\hline Total fatty acids ${ }^{b}$ & 14.3 \\
\hline Phosphate $^{b}$ & 0.6 \\
\hline Nucleic acids ${ }^{b}$ & 0 \\
\hline Protein ${ }^{b}$ & 0.6 \\
\hline \multicolumn{2}{|c|}{$\begin{array}{l}\text { Determined by GLC on a } 2 \mathrm{~m} \times 0.31 \mathrm{~cm} \text { glass column } \\
\text { containing } 10 \% \text { SP2330 on } 100 / 120 \text { Gas Chrom W AW } \\
\text { The unidentified represents the sum of } 7 \text { components } \\
\text { Determined colorimetrically }\end{array}$} \\
\hline
\end{tabular}

the presence of 3-deoxy-D-manno-octulosonic acid, glucose, rhamnose, fucose, ribose, xylose, mannose, galactose, inositol, D-glycerol-D-mannoheptose, Dglycero-L-mannoheptose and 3- or 4-0 methyl hexose.
Glycerol was also identified in the hydrolysate. Seven unidentified minor components were detected by GLC in the area where deoxyhexoses and pentoses elute. Glucosamine was the only amino sugar identified. The principal acids of the LPS were 16:0,16:1 and 3-OH14:0 (Table 1). Small amounts of $3-\mathrm{OH}-\mathrm{C}_{16}$ were also detected.

The results from the test of the Limulus lysate activities of the LPS of Spirulina platensis and Salmonella abortus equi are given in Table 3 . Gelation of the Limulus lysate assay with LPS of $S$. platensis and $S$. abortus equi occurred with a concentration of $10^{-9} \mu \mathrm{g}$ $\mathrm{ml}^{-1}$ and $10^{-12} \mu \mathrm{g} \mathrm{ml} \mathrm{m}^{-1}$, respectively. These results demonstrated that the LPS of $S$. platensis was toxic. The toxic properties of LPS preparations were also measured by intraperitonal injections into mice. The lethal dose of LPS from $S$. platensis was $8.5 \mathrm{mg}$ ani$\mathrm{mal}^{-1}$ as compared to $0.8 \mathrm{mg}$ animal ${ }^{-1}$ for LPS of $S$. abortus equi. Similar toxicity has been observed in LPS preparations isolated from different commercial sources of $S$. platensis.

\section{DISCUSSION}

The lipid analysis of Spirulina platensis showed a relatively simple composition and one that has been previously described for blue-green bacteria (Appleby et al. 1971, Weckesser et al. 1974, Sato et al. 1979). One exception, however, is the occurrence of the lyso-forms of digalactosyl diacylglycerol and phosphatidyl diacylglycerol. The relatively large portion of $\mathrm{C}_{18}$ polyun- 
Table 3. Limulus amoebocyte lysate activity of the Lipopolysaccharides of Spirulina platensis and Salmonella abortus equi

\begin{tabular}{|c|c|c|c|c|c|c|c|c|}
\hline \multirow[t]{2}{*}{ Lipopolysaccharides } & \multicolumn{8}{|c|}{$\mu \mathrm{g} \mathrm{ml}^{-1}$} \\
\hline & $10^{-6}$ & $10^{-7}$ & $10^{-8}$ & $10^{-9}$ & $10^{-10}$ & $10^{-11}$ & $10^{-12}$ & $10^{-13}$ \\
\hline S. platensis & $+++^{c}$ & +++ & ++ & \pm & - & & & \\
\hline S. abortus equi ${ }^{\text {b }}$ & $+t+$ & +++ & $+t+$ & $+t+$ & $++t$ & ++ & \pm & - \\
\hline \multicolumn{9}{|c|}{$\begin{array}{l}\text { activity of different concentrations of LPS, determined by incubating } 0.1 \mathrm{ml} \text { of the test sample with an equal volume of } \\
\text { Limulus amoebocyte lysate at } 37^{\circ} \mathrm{C} \text { in a stoppered } 10 \times 75 \mathrm{~mm} \text { glass test tube } \\
\text { b Lipopolysaccharide standard obtained from Sigma } \\
\text { c }+++ \text { Solid gel formed in less that } 60 \mathrm{~min} ;++ \text { solid gel formed after } 60 \mathrm{~min} ; \pm \text { viscous or granular gel formed after } \\
60 \mathrm{~min} ;- \text { no gel formed after } 24 \mathrm{~h}\end{array}$} \\
\hline
\end{tabular}

saturated fatty acid has been previously recognized in Cyanophytes and well reviewed (Stanier \& CohenBazire 1977), and their existence in Cyanophytes remains an exception to the general prokaryotic rule that polyunsaturated fatty acids do not occur in bacteria.

The fatty acid content of LPS was different from those in the free lipid fraction by the presence of $\mathrm{OH}$ $\mathrm{C} 14$ and $\mathrm{OH}-\mathrm{C} 16$ acids. These findings are similar to previous reports on LPS preparations from other Cyanobacteria (Weckesser et al. 1979). The sugar composition of the LPS preparation was fairly typical of many Gram-negative bacteria.

The toxicity of the LPS preparation was very significant but lower relative to the toxicity of LPS of Salmonella abortus equi. Toxicity in Cyanophytes has been shown to be dependent of many different environmental and physiological factors such as light, temperature, pH, nutrients, mixing, etc. (Carmichael \& Gorham 1980). At this early stage it is not clear whether the LPS toxicity of $S$. platensis is environment dependent, but the presence of toxicity in various different commercial preparations of $S$. platensis points to a basic inherent level of toxicity in S. platensis.

\section{LITERATURE CITED}

Albersheim, P., Nevins, K. J., English, P. D., Kann, A. (1967). A method for the analysis of sugars in plant cell-wall polysaccharides by gas liquid chromatography. Carbohydr. Res, 5: 304-345

Appleby, R. S., Safford, R., Nichols, B. W. (1971). The involvement of lecithin and monogalactosyl diglyceride in Iinoleate synthesis by green and blue-green algae. Biochim. biophys. Acta 248: 205-211

Bartlett, G. R. (1959). Phosphorus assay in column chromatography. J. biol. Chem. 234; 466-468

Bligh, E. G., Dyer, W. J. (1959). A rapid method of total lipid extraction and purification. Can. J. Biochem. Physiol. 37 : 911-917

Boas, N. F. (1953). Method for the determination of hexosamines in tissues. J. biol. Chem. 204: 553-563

Carmichael, W. W., Gorham, P. R. (1980). Freshwater cyanophyte toxins: types and their effect on the use of microalgae biomass. In: Shelef, G., Soeder, C. J. (ed.) Algal biomass. North Holland Biomedical Press, Amsterdam, p. 438-448

Cynkin, M. A., Ashwell, G. (1960). Estimation of 3-deoxy sugars by means of the malonaldehyde-thiobarbituric acid reaction. Nature, Lond. 186: 155-156

Gentile, J. H. (1971). Blue-green and green algal toxıns. In: Kadis, S., Cieglar, A., Ajl, S. J. (ed.) Microbial toxins, Vol. 7. Academic Press, New York, p. 27-66

Jensen, A. (1973). Chlorphyll and carotenoids. In: Hellebust, J. A., Craigie, J. S. (ed.) Handbook of phycological methods. Cambridge University Press, Cambridge, p. $59-70$

Kates, M. (1971). Techniques in lipodology, isolation, analysis and identification of lipids. In: Work, T. S., Work, E. (ed.) Laboratory techniques in biochemistry and molecular biology. Elsevier/North Holland, Amsterdam, p. 268-504

Kates, M., Adams, G. A., Martin, S. M. (1964). Lipids of Serratia marcescens. Can. J. Biochem. 42: 461-479

Keleti, G., Sykora, J. L., Maiulie, L. A., Doerfler, D. L., Campbell, I. M. (1981). Algal toxins. In: Carmichael, W. W. (ed.) The water environment algal toxins and health. Plenum Press, New York, p. 447-464

Kochert, G. (1973a). A protein determination by binding. In Hellebust, J. A., Craigie, J. S. (ed.) Handbook of phycological methods. Cambridge University Press, Cambridge, p. 91-93

Kochert, G. (1973b). Carbohydrate determination by the phenol-sulfuric acid method. In: Hellebust, J. A., Craigie, J. S. (ed.) Handbook of phycological methods. Cambridge University Press, Cambridge, p. 95-97

Raziuddin, S. (1976). Characterization of lipid A and polysaccharide moiety of the lipopolysaccharide from Vibrio cholerae. Biochem. J. 167: 147-154

Richmond, A., Karg, S., Boussiba, S. (1982). Effect of bicarbonate and carbon dioxide on competition between Chlorella vulgaris and Spirulina platensis. Pl. Cell Physiol., Tokyo 23: 1411-1417

Sato, N., Murata, N. (1982). Lipid biosynthesis in the bluegreen alga Anabaena variabilis. Biochim. biophys. Acta 710: $271-278$

Sato, N., Murata, N., Miura, Y., Ueta, N. (1979). Effect of growth temperature on lipid and fatty acid composition in the blue-green algae. Anabaena variabilis and Anacystis nidulans. Biochim. biophys. Acta 572: 19-20

Short, S. A., White, D. C., Aleem, M. I. H. (1969). Phospholipid metabolism in Ferrobacillus ferroxidans. J. Bacteriol. 99: $142-150$

Stanier, R. Y., Cohen-Bazire, G. (1977). Phototrophic prokaryotes: the Cyanobacteria. A. Rev. Microbiol. 31: 225-274

Tornabene, I G. (1980). Formation of hydrocarbons by bac- 
teria and algae. In: Hollaender, A., Rabson, R., Rogers, S., San Pietro, A., Valentine, R., Wolf, R. (ed.) Trends in the biology of fermentations for fuels and chemicals. Plenum Press, New York, p. 421-430

Tornabene, T. G., Kates, M., Gelpi, E., Oro, J. (1969). Occurrence of squalene, di- and tetrahydrosqualene, and vitamin Mk8 in an extremely halophilic bacterium, Halobacterium cutirubrum. J. Lipid Res. 10: 294-303

Tornabene, T. G., Ogg, J. E. (1971). Chromatographic studies of the lipid components of Vibrio fetus. Biochim. biophys. Acta 239: 133-141

Vaskovsky, V. E., Svetashev, V. I. (1972). Phospholipid spray reagents. J. Chromat. $65: 451-453$

Vonshak, A., Abeliovich, A., Boussiba, S., Arad, S., Richmond, A. (1982). Production of Spirulina biomass: effects of environmental factors and population density. Biomass 2: $175-185$

Vonshak, A., Boussiba, S., Abeliovich, A., Richmond, A. (1983). Production of Spirulina biomass: maintenance of monoalgal culture outdoors. Biotechnol. Bioeng. 25: $341-345$

Warren, L. (1959). The thiobarbituric acid assay of sialic acids. J. biol. Chem. 234: 1971-1975
Weckesser, J., Drews, G., Mayer, H. (1979). Lipopolysaccharides of photosynthetic prokaryotes. A. Rev. Microbiol. 33: $215-239$

Weckesser, J., Katz, A., Drews, G., Mayer, H., Fromme, I. (1974). Lipopolysaccharide containing L-Acofriose in the filamentous blue-green alga Anabaena variabilis. J. Bact. 120: 672-678

Weise, G., Drews, G., Jann, B., Jann, K. (1970). Identification and analysis of a lipopolysaccharide in cell walls of the blue-green alga Anacystis nidulans. Arch. Mikrobiol. 71: 89-98

Westphal, O., Lüderitz, O., Bister, F. (1952). Über die Extraktion von Bakterien mit Phenolwasser. Z. Naturforsch. 7b: 148-155

Wright, B. G., Rebers, P. A. (1972). Procedure for determining heptose and hexose in lipopolysaccharides, modification of the cysteine-sulfuric acid method. Analyt. Biochem. 49: 307-319

Yanagimoto, M., Saitoh, H. (1982). Evaluation tests of a large spiral blue-green alga, Oscillatoria sp., for biomass production. J. Ferment. Technol. 60: 305-310

This paper was submitted to the editor; it was accepted for printing on December 16, 1984 